\title{
Some fixed points results on Branciari metric spaces via implicit functions
}

\author{
ERDAL KARAPINAR ${ }^{1,2}$
}

\section{ABSTRACT.}

In this paper, we introduce the notion of $\alpha$-implicit contractive mapping of integral type in the context of Branciari metric spaces. The results of this paper, generalize and improve several results on the topic in literature. We give an example to illustrate our results.

\section{REFERENCES}

[1] Ali, M. U. and Kamran, T., On $\left(\alpha^{*}, \psi\right)$-contractive multi-valued mappings, Fixed Point Theory Appl., 2013 2013:137

[2] Ali, M. U., Kamran, T., and Karapınar, E., An Approach to Existence of Fixed Points of Generalized Contractive Multivalued Mappings of Integral Type via Admissible Mapping, Applied and Abstract Analysis, (2014), Article Id:141489

[3] Aydi, H., Karapınar, E.,and Samet, B., Fixed points for generalized $(\alpha, \psi)$-contractions on generalized metric spaces, Journal of Inequalities and Applications, (2014)

[4] Aydi, H., Karapınar, E. and Lakzian, H., Fixed point results on the class of generalized metric spaces, Math. Sciences, 2012, 6:46

[5] Azam, A. and Arshad, M., Kannan fixed point theorems on generalized metric spaces, J. Nonlinear Sci. Appl., 1 (2008), 45-48

[6] Branciari, A. , A fixed point theorem of Banach-Caccioppoli type on a class of generalized metric spaces, Publ. Math. Debrecen, 57 (2000), 31-37

[7] Branciari, A. , A fixed point theorem for mappings satisfying a general contractive condition of integral type, Int. J. Math. Math. Sci., 29 (2002), No. 9, 531-536

[8] Bilgili, N. and Karapınar, E., A note on "common fixed points for $(\psi, \alpha, \beta)$-weakly contractive mappings in generalized metric spaces", Fixed Point Theory Appl., 2013, 2013:287

[9] Das, P. and Lahiri, B. K. , Fixed point of a Ljubomir Ćirić's quasi-contraction mapping in a generalized metric space, Publ. Math. Debrecen, 61 (2002), 589-594

[10] Erhan, I. M., Karapınar, E. and Sekulić, T., Fixed points of $(\psi, \phi)$ contractions on rectangular metric spaces, Fixed Point Theory Appl., 2012, 2012:138

[11] Jleli, M., Karapinar, E. and Samet, B., Best proximity points for generalized $\alpha-\psi$-proximal contractive type mappings, Journal of Applied Mathematics, Article ID 534127, (2013)

[12] Jleli, M., Karapınar, E. and Samet, B., Fixed point results for $\alpha-\psi_{\lambda}$ contractions on gauge spaces and applications, Abstract and Applied Analysis, (2013) Article Id, 730825

[13] Jleli, M. and Samet, B., The Kannan's fixed point theorem in a cone rectangular metric space, J. Nonlinear Sci. Appl., 2 (2009), No. 3, 161-167

[14] Kadeburg, Z. and Radenovic̀, S., On generalized metric spaces: a survey, TWMS J. Pure Appl. Math., 5 (2014), No. 1, 3-13

[15] Karapınar, E., Discussion on $(\alpha, \psi)$ contractions on generalized metric spaces, Abstract and Applied Analysis, (2014) Article ID 962784

[16] Karapınar, E., Fixed points results for alpha-admissible mapping of integral type on generalized metric spaces, Abstract and Applied Analysis, (2014), Article Id: 141409

Received: 26.08.2014; In revised form: 20.03.2015; Accepted: 22.03.2015

2010 Mathematics Subject Classification. 46T99, 47H10, 54H25.

Key words and phrases. Generalized metric spaces, implicit function, Branciari metric spaces. 
[17] Karapınar, E., On $(\alpha, \psi)$ contractions of integral type on generalized metric spaces, in Proceedings of the 9th ISAAC Congress, V. Mityushevand, M. Ruzhansky, Eds., Springer, Krakow, Poland, 2013

[18] Karapinar, E. and Samet, B., Generalized $\alpha$ - $\psi$-contractive type mappings and related fixed point theorems with applications, Abstract Appl. Analysis, 2012 (2012), Article ID 793486

[19] Kikina, L. and Kikina, K., A fixed point theorem in generalized metric space, Demonstrateio Mathematica, XLVI (2013), No. 1, 181-190

[20] Kirk, W. A. and Shahzad, N., Generalized metrics and Caristis theorem, Fixed Point Theory Appl., 2013, 2013:129

[21] Kirk, W. A. and Shahzad, N., Correction: Generalized metrics and Caristis theorem, Fixed Point Theory Appl.,2014, 2014:177

[22] Mihet, D., On Kannan fixed point principle in generalized metric spaces, J Nonlinear Sci Appl., 2 (2009), No. 2, 92-96

[23] Popa, V., Implicit Contractive Maps in Ordered Metric Spaces, Topics in Mathematical Analysis and Applications Springer Optimization and Its Applications, Volume 94, 2014, pp 715-746

[24] Popa, V., Fixed point theorems for implicit contractive mappings, St. Cerc. t. Univ. Bacu (Ser. Math.), 7 (1997) 129-133

[25] Popa, V., Some fixed point theorems for compatible mappings satisfying an implicit relation, Dem. Math., 32 (1999) $157-163$

[26] Popa, V., On some fixed point theorems for mappings satisfying a new type of implicit relation, Math. Moravica, 7 (2003), 61-66

[27] Popa, V. and Mocanu, M., Altering distance and common fixed points under implicit relations, Hacettepe J. Math. Stat., 38 (2009) 329-337

[28] Samet, B., A fixed point theorem in a generalized metric space for mappings satisfying a contractive condition of integral type, Int. J. Math. Anal., 26 (2009), No. 3, 1265-1271

[29] Samet, B., Discussion on: a fixed point theorem of Banach-Caccioppoli type on a class of generalized metric spaces by A. Branciari, Publ. Math. Debrecen, 76 (2010), No. 4, 493-494

[30] Samet, B., Vetro, C. and Vetro, P., Fixed point theorems for $\alpha$ - $\psi$-contractive type mappings, Nonlinear Anal., 75 (2012) 2154-2165

[31] Sarma, I. R., Rao, J. M. and Rao, S. S., Contractions over generalized metric spaces, J. Nonlinear Sci. Appl., 2 (2009), No.3, 180-182

[32] Suzuki, T., Generalized metric space do not have the compatible topology, Abstract Appl. Anal., vol. 2014, Article ID 458098, 5 pages, 2014

[33] Turinici, M., Fixed points of implicit contraction mappings, An. Şt. Univ. "A. I. Cuza" Iaşi (S I-a, Mat), 22 (1976), $177-180$

${ }^{1}$ Department of Mathematics, Atilim University

06836 INCEK, ANKARA-TURKEY

2 Nonlinear Analysis and Applied Mathematics Research Group (NAAM)

King ABdulaZIZ UNIVERSITY, JEDDAH, SAUdi ARABIA

E-mail address: erdalkarapinar@yahoo.com, erdal.karapinar@atilim.edu.tr 